\title{
The effect of modern medical technology on the availability and cost of cataract treatment in older patients
}

\author{
JOANNA FURTAK-POBROTYN ${ }^{1, A-F}$, PIOTR POBROTYN², A-F, IZABELA WITCZAK ${ }^{3, \text { B-F}}$, \\ ŁUKASZ RYPICZ ${ }^{3, B-F}$, ROBERT SUSŁO ${ }^{4, D-F}$, RENATA JAŻDŻ-ZALESKA ${ }^{5, D}$, JAROSŁAW DROBNIK ${ }^{4, A, C, D}$ \\ 1 "Citodent" Dental Care Center, Oława, Poland \\ ${ }^{2}$ University Clinical Hospital in Wrocław, Poland \\ ${ }^{3}$ Economics and Quality in Health Care Unit, Public Health Department, Health Sciences Faculty, Wrocław Medical \\ University, Poland \\ ${ }^{4}$ Gerontology Unit, Public Health Department, Health Sciences Faculty, Wrocław Medical University, Poland \\ ${ }^{5}$ Specjalistyczne Centrum Medyczne S.A., Polanica Zdrój, Poland
}

A - Study Design, B - Data Collection, C - Statistical Analysis, D - Data Interpretation, E - Manuscript Preparation, F - Literature Search, G - Funds Collection

Summary Background. The average waiting time for cataract treatment in Poland is 441 days - the longest for any surgical procedures in the country.

Objectives. The aim of the study was to examine the availability of surgical cataract treatment among older Polish patients.

Material and methods. Using data from 25,970 hospitalizations at the Ophthalmology Ward of the University Clinical Hospital in Wrocław, Poland in years 2012-2017, we analyzed the demographic structure of the patients, the duration of hospital stay, and the average cost; the level of statistical significance was taken to be $p<0.05$.

Results. Patients 65 years of age or older made up $78 \%$ of patients receiving surgical cataract treatment. This treatment required significantly shorter hospitalization time in 2017 than in 2012 (an average of 1.89 vs. 2.19 patient-days, respectively). The average hospital stay length among the older patients was significantly shorter than among younger patients ( 2.3 vs 3.2 patient-days, respectively) and the average hospitalization cost for patients aged 65 years or older was significantly lower (2105.63 PLN vs 2929.57 PLN, equivalent of 495.44 EUR vs 689.31 EUR, respectively).

Conclusions. The duration of the average hospital stay in the ophthalmology ward was shorter, and the average hospitalization cost was lower, for patients aged 65 years or older than for younger patients because older patients mostly undergo modern standardized less-invasive cataract treatment. As more ophthalmological medical staff, infrastructure, and financial assets are available for cataract treatment and have not yet been assigned or spent, Polish hospitals should introduce newer medical technology, process adjustments, and organizational innovations to fully utilize their potential and improve the availability of cataract treatment.

Key words: technology, economics, medical, patient care management, cataract, health services accessibility.

Furtak-Pobrotyn J, Pobrotyn P, Witczak I, Rypicz $九$, Susło R, Jażdż-Zaleska R, Drobnik J. The effect of modern medical technology on the availability and cost of cataract treatment in older patients Fam Med Prim Care Rev 2018; 20(3): 222-226, doi: https://doi.org/10.5114/ fmpcr.2018.78255.

\section{Background}

The impairment and subsequent loss of vision are significant and increasing problems in old-age health care. The most common causes of vision loss in elderly patients include cataract, glaucoma, age-related degeneration of the macula, and diabetic retinopathy [1]. Acquired cataract is precipitated by aging-related or other metabolic disturbances in the lens. According to the World Health Organization, cataract is the leading cause of vision deterioration and loss around the world. It is estimated that around 17 million people suffer from reversible blindness, and this number continues to increase [2]. Age-related cataract is the most common form of acquired cataract, with pathological changes beginning as early as 40 years of age and clinically manifesting 10-20 years later [3]. The number of people suffering from cataract-related reversible blindness who can be treated surgically thus increases with the increasing average life-span. In order to keep up with this growing demand, it is crucial to develop and implement state-of-the-art technologies in ophthalmology [4]. Cataract surgery systems optimized for maximizing efficacy and lowering costs are currently being developed; they need to provide a reasonable level of safety to patients while securing acceptable levels of ophthalmology ward throughput [5]. Hospitals therefore need to implement modern methods of cataract treatment along with organizational innovations.

The average waiting time for surgical cataract treatment in Poland is 441 days, the longest of all the OECD countries (Figure 1); Estonia has the second-longest waiting time at 253 days [6]. It is also the longest waiting time for any surgical procedures in Poland, as this operation is underfunded by the Polish public health insurance fund (Narodowy Fundusz Zdrowia, NFZ), especially when the growing demand is considered. The costs resulting from these long waiting times are burdensome not only for patients and their caregivers, but also to society as a whole. Although the number of surgical cataract procedures carried out in Poland has risen significantly from 166,610 procedures in 2010 to 220,849 in 2014 [7], the number of patients on the waiting list has rapidly increased: in 2012-2016, this increase was observed both for urgent cases $(18,848$ vs 25,095 patients waiting, respectively) and for planned procedures $(382,019$ vs 518,845 patients waiting, respectively). Only in 2017 has the length of both these waiting lists shrunk slightly (to 23,125 and 471,929 patients, respectively) as the number of surgical cataract procedures carried out on Polish patients increased 


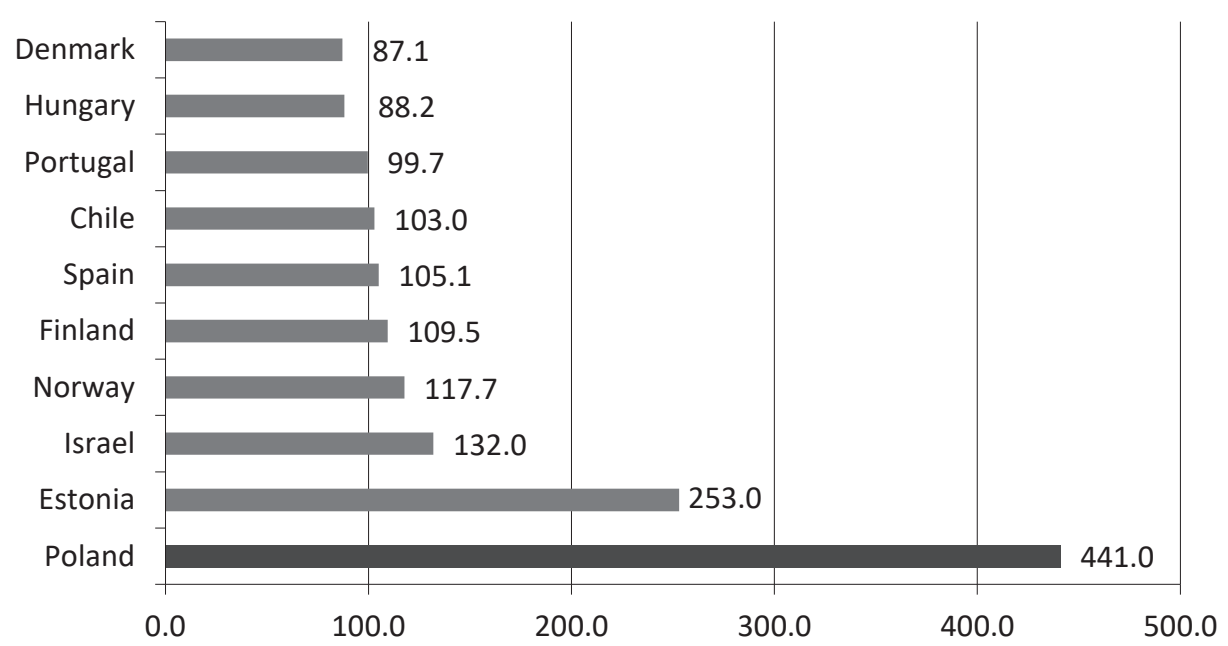

Figure 1. Average waiting time for surgical cataract treatment in selected OECD countries [days]

Source of data: [6].

- though this includes those who had the operation abroad. Even increased financial coverage of cataract treatment in Poland does not directly translate into better availability of the medical procedure: between January and November of the year 2016, the NFZ increased funding for cataract treatment by over 35 million PLN (around 8.2 million EUR), but in December of the same year, 23 medical facilities returned 2.6 million PLN (around 0.6 million EUR) they were incapable of spending [8]: they were unprepared to carry out all the procedures they had contracted to undertake, which resulted in the treatment being limited to patients who needed it. This situation forced waiting patients to use their right to be treated in other countries of the European Union. Directive 2011/24/EU on patients' rights in cross-border healthcare enables Polish patients to receive reimbursement of treatment costs from the NFZ. Around $92.3 \%$ of all reimbursement requests based on the Directive filed in 2017 with the NFZ related to the costs of surgical cataract treatment - which translates into a stunning total of 33,675,580.88 PLN (about 7.9 million EUR) [9].

According to data from the Polish national statistics office (Główny Urzq̨d Statystyczny, GUS), in 2010-2016, the number of physicians specializing in ophthalmology increased in Poland (from 1753 to 2018, respectively), and the average number of ophthalmology per million people in Poland exceeds the average for the European Union generally (111 vs 82, respectively). Yet there are numerous unused hospital beds in ophthalmology wards in practically all regions of Poland: from $31 \%$ in Swiętokrzyskie Voivodeship to as much as $64 \%$ in the Lubelskie Voivodeship [10]. The aging of society in Poland is leading to an increase in the demand for cataract surgical treatment, which requires specific adjustments in hospital infrastructure. This triggered the increase in the number of ophthalmology wards observed in the period 2010-2016 (from 139 to 185, respectively), as reported by GUS.

\section{Objectives}

The aim of this study was to examine the problem of the availability of cataract surgical treatment in Poland on the basis of the records of the Ophthalmology Ward at the University Clinical Hospital in Wrocław, Poland.

\section{Material and methods}

Using data on 25,970 hospitalizations in the Ophthalmology Ward of the University Clinical Hospital in Wrocław, Poland in 2012-2017, we examined the demographic structure of the patients, the length of the hospital stay, and the average cost of hospitalization. Statistical analysis was performed in Statistica 13.1 PL. The data were tested for normal distribution (Lillefors test) and, as the hypothesis of normal data distribution was rejected, comparisons between groups were performed using the nonparametric Mann-Whitney U-test. Distributions of qualitative variables were analyzed by cross-tabulation and the chi-squared Pearson test. Statistical significance was taken as $p<0.05$.

The study was approved by the Bioethics Committee of the Wrocław Medical University, Poland (identification number of the opinion: KB.-608/2017).

\section{Results}

In 2012-2017 in the Ophthalmology Ward at the University Clinical Hospital, there were total of 12,265 hospitalizations (48.6\%) for surgical treatment of cataract and 13,345 hospitalizations (51.4\%) for other reasons. In the examined period, among the group of patients admitted for surgical cataract treatment, the number of patients 65 years of age or older increased from 1449 to 1755 (Figure 2). These older patients made up 78\% of all patients who underwent surgical cataract treatment in the period 2012-2017.

Patients undergoing cataract treatment needed shorter hospitalizations in 2017 (an average of 1.89 patient-days) than in 2012 (an average of 2.19 patient-days); also, the ratio of hospitalization time for surgical cataract treatment to hospitalization time for other reasons (Figure 3) decreased significantly (in 2012 , this ratio was 2.19:3.07 $=0.71$ and in 2017 it was 1.89:2.96 $=0.64$ ).

Patients 65 years and older are admitted to the Ophthalmology Ward predominantly for surgical cataract treatment, which on average needs a shorter hospital stay (generally one day) than most other hospitalization reasons; these other reasons dominate among patients under 65 . The average hospitalization time among the older patient group is thus significantly shorter than among younger patients (2.3 patient-days vs 3.2 patientdays, respectively).

Analysis of the hospital stay duration in terms of the cause of hospitalization showed that patients aged 65 years and older spend less time in hospital compared than younger patients, both in the case of surgical cataract treatment and other treatment causes (Figure 4). 


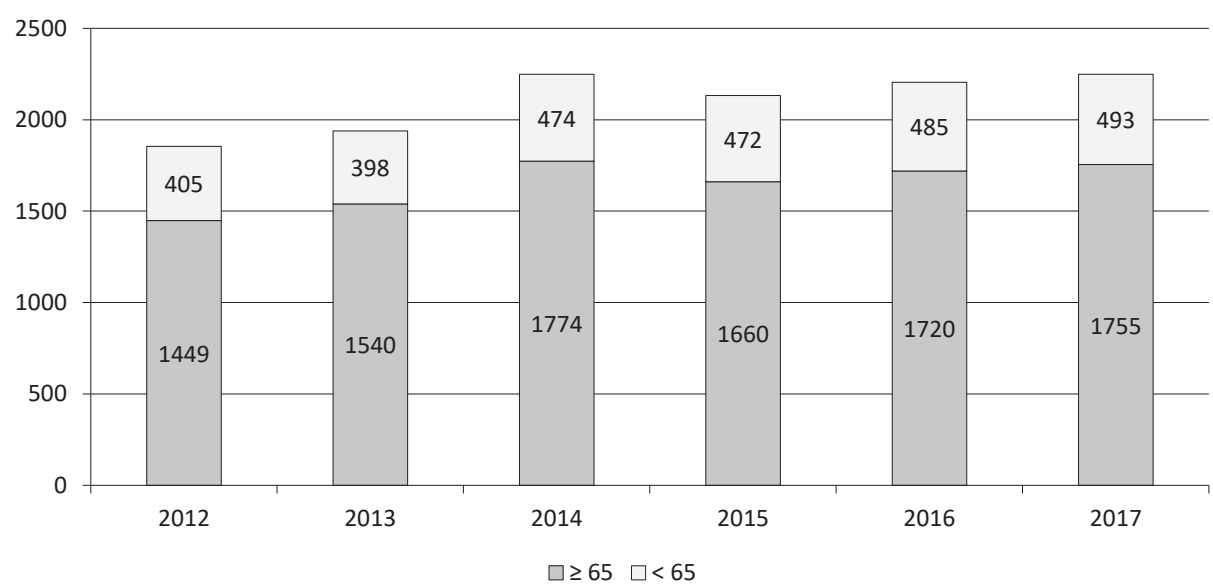

Figure 2. Number of patients treated for cataract in 2012-2017 in the Ophthalmology Ward of the University Clinical Hospital in Wroclaw, Poland, by age: 65 years and older and up to 65 years [number of patients]

Source of data: University Clinical Hospital information system.

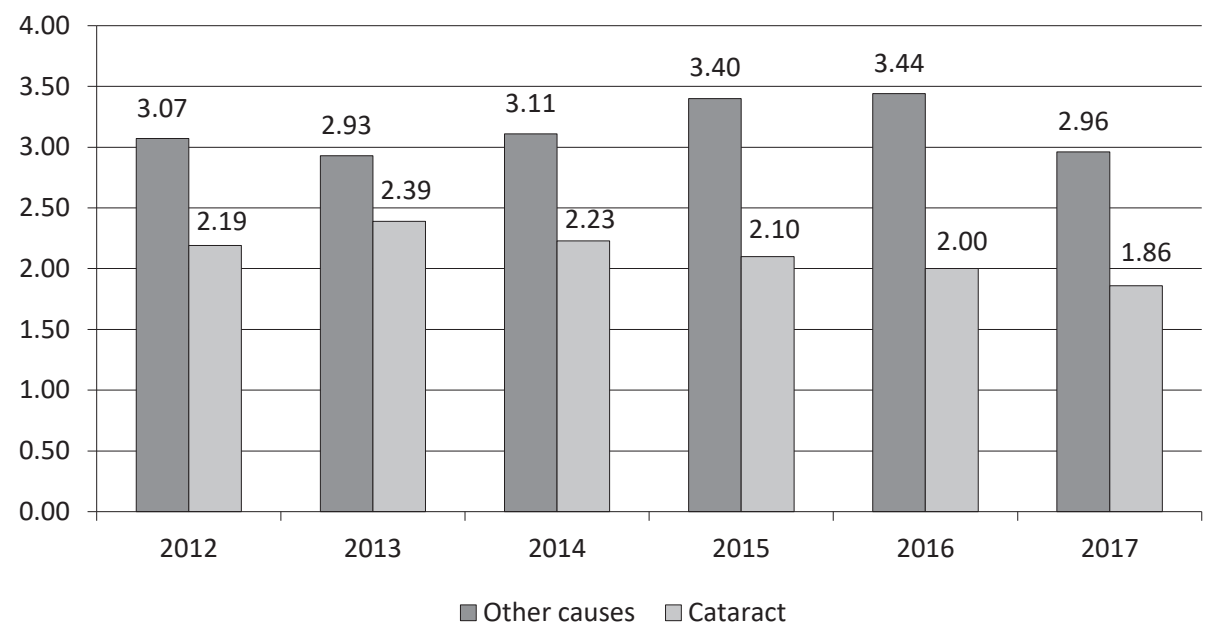

Figure 3. Average length of stay of patients treated for cataract and other causes in 2012-2017 in the Ophthalmology Ward of the University Clinical Hospital in Wroclaw, Poland [patient-days]

Source of data: University Clinical Hospital information system.

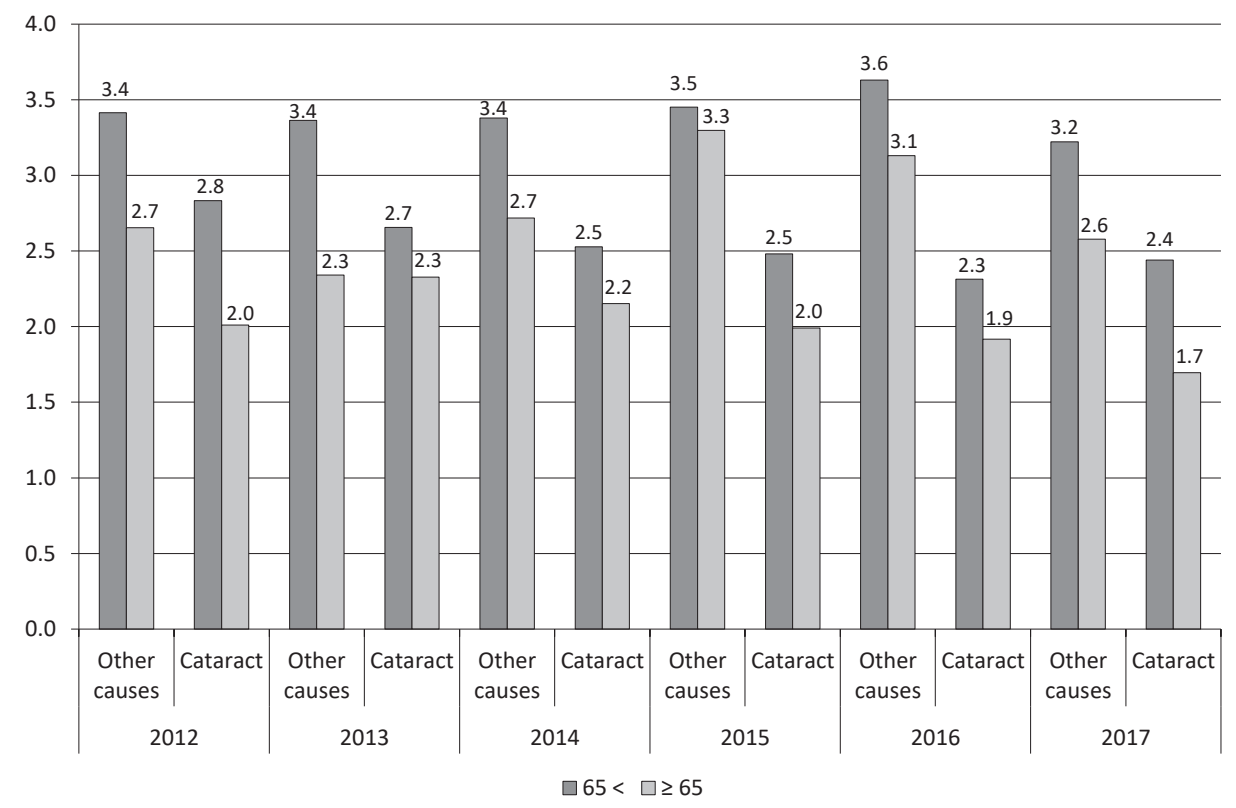

Figure 4. Average length of stay of patients treated for cataract and other causes in 2012-2017 in the Ophthalmology Ward of the University Clinical Hospital in Wroclaw, Poland, by age groups: 65 years and older and up to 65 years [patient-days]

Source of data: University Clinical Hospital information system. 
Consistently, the average cost of hospitalization of patients aged 65 years and older in the Ophthalmology Ward of the University Clinical Hospital in 2012-2017 was significantly lower than in the case of younger patients (2105.63 PLN vs 2929.57 PLN, respectively; equivalent of 495.44 EUR vs 689.31 EUR, accepting the average PLN to EUR exchange rate $4.25: 1$ ).

\section{Discussion}

There are many possible causes for the limited availability of medical services. Current demographic phenomena-particularly the aging of society combined with prolonged life spans -are the direct causes of increased demand for medical services. On the other hand, the availability of these services can be limited by a lack of financial assets, a deficit of specialized medical staff, or patients' preference for medical services provided in a certain type of medical facilities [1]. The increasing expectations of quality of life among aging patients mean that modern medical technologies must be used to treat age-related vision impairment [11]. It is also necessary to introduce process adjustments and organizational innovations in hospitals [12] in order to lower the costs of medical services and improve their quality and availability.

Although both staff specialized in ophthalmology and the necessary medical infrastructure are available in Poland, and are comparable with the standards of other developed countries, surgical cataract treatment waiting times in Poland are among the longest in the entire OECD. This can be attributed in the first place to organizational faults in ophthalmology wards which make it impossible to utilize their full potential. Hospitals are the most complex facilities that providing medical services, in both economic and financial terms, and also on account of the wide variety of assets utilized and activities carried out. Efficient financial policy is needed for both every-day and long-term hospital functioning, so choosing the most appropriate tools is crucial if the positive effects are to be maximized [12]. The current limited availability of cataract treatment in Poland, together with the option of seeking medical help in other countries of the European Union made available to Polish patients by Directive 2011/24/EU [13], has led to an increased transfer of financial assets from the NFZ to medical service providers abroad. Undergoing surgical cataract treatment abroad seems to be attractive to patients in all parts of Poland [8], but in practice the vast majority $(85 \%)$ of beneficiaries are inhabitants of the southern regions of Poland, namely the Dolnoslaskie, Slaskie, and Malopolskie voivodeships. Since the capacity does exist in Polish hospitals to provide more surgical cataract treatment procedures, organizational efforts should be made by the

Source of funding: This work was funded by the authors' resources. Conflict of interest: The authors declare no conflict of interests.

\section{References}

1. Wierzbowska J, Stankiewicz A. Choroby oczu w wieku podeszłym. Med Dyp/ 2011; 8(185): 46-51 (in Polish).

2. Grzybowski A, Gaca-Wysocka M. Zaćma. In: Grzybowski A. Okulistyka. Wrocław: Wydawnictwo Edra Urban \& Partner; 2018: 147-148 (in Polish).

3. Niżankowska M. Okulistyka - podstawy kliniczne. Warszawa: Wydawnictwo Lekarskie PZWL; 1986: 288-289 (in Polish).

4. Kałużny J, Seredyka-Buduk M. Stan obecny i perspektywy rozwoju chirurgii zaćmy. In: Kęcik T, ed. Okulistyka Polska poczqtku XXI wieku. Warszawa: Wydawnictwo OFTAL; 2002: 20-21 (in Polish).

5. Spaeth G. Chirurgia okulistyczna. Wrocław: Elsevier Urban \& Partner; 2006: 6-9 (in Polish).

6. OECD/EU. Health at a Glance: Europe 2016 - State of Health in the EU Cycle. Paris: OECD Publishing; 2016: 176-177, doi: http://dx.doi. org/10.1787/9789264265592-en.

7. Grzybowski A, Maciejewski A. Koszty społeczne odroczonego terminu zabiegu usunięcia zaćmy z jednoczesnym wszczepieniem soczewki. Ophtha Therapy 2016; 1(9): 53-58 (in Polish).

8. Grzybowski A, Maciejewski A. Wzrost liczby operacji usunięcia zaćmy wykonywanych w ramach dyrektywy transgranicznej z $2016 \mathrm{r}$. Ophtha Therapy 2017; 1(13): 10-14 (in Polish).

9. Narodowy Fundusz Zdrowia. Sprawozdanie z działalności Narodowego Funduszu Zdrowia za rok 2017. Warszawa: NFZ; $2018: 64$ [cited 24.07.2018]. Available from URL: http://www.nfz.gov.pl/gfx/nfz/userfiles/_public/bip/dzialalnosc_nfz/sprawozdania_z_dzialalnosci_ nfz/sprawozdanie_z_dzialalnosci_nfz_za_2017_rok.pdf (in Polish).
NFZ to apply more of its financial assets to medical services proin Poland, rather than paying for them abroad.

een in this study can be explained mainly by the difference in case characteristics in the different age groups: in the older patients, devolution- and degeneration-related conditions domiby comorbidities) seen in younger patients; these require loncan be attributed to (among other causes) the shorter hospital

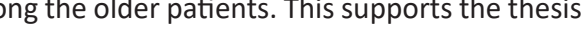

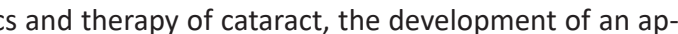
improving management make it possible to shorten the aver列 costs, as we observed in the study results. The resulting financial savings are significant not only to individual medical service providers, but also to the public medical insurance fund NFZ.

\section{Conclusions}

In the Ophthalmology Ward of the University Clinical HospiWor average hospitization cost was lower can be attributed to the fact that the older patients are admitted

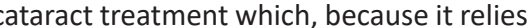
standardized, relatively quick, and less-invasive procedure that needs of aging Polish society can be more effectively fulfilled

are comparable to OECD standards, and since there are finaned to be spent in Poland, Polish hospitals should not only introof surgical cataract treatment to patients improves, shortening waiting lists. tal in Wrocław, Poland, in 2012-2017, the average hospital stay potential is used to a greater extent, and the real availability 
10. Wilczyńska J, Bogusławski S, Plisko R, Raport: Leczenie zaćmy jednq z największych niezaspokojonych potrzeb zdrowotnych polskiego społeczeństwa. Warszawa Sequence HC Partners Sp. z o.o., HTA Consulting Sp. z o.o.; 2012 (in Polish).

11. Grabska-Liberek I, Derlacka D, Skowyra A. Nowoczesne metody leczenia zaćmy. Post Nauk Med 2013; 12: 880-883 (in Polish).

12. Witczak I. Ekonomika szpitala, uwarunkowania, elementy, zasady. Warszawa: Wydawnictwo CeDeWu; 2009: $150-153$ (in Polish).

13. Dyrektywa Parlamentu Europejskiego i Rady 2011/24/UE z dnia 9 marca 2011 r. w sprawie stosowania praw pacjentów w transgranicznej opiece zdrowotnej (Dz.U. UE L. 88 z dn. 4.04.2011) (in Polish).

Tables: 0

Figures: 4

References: 13

Received: 06.08.2018

Reviewed: 11.08 .2018

Accepted: 14.08 .2018

Address for correspondence:

Robert Susło, MD, PhD

Zakład Gerontologii

Katedra Zdrowia Publicznego UM

ul. Bartla 5

51-618 Wrocław

Polska

Tel.: +48 71 347-90-29

E-mail: robertsuslo@gmail.com 